\title{
MODEL PENGGUNAAN ULANG KLIEN TERHADAP JASA PSIKOLOGI BERBASIS KEPERCAYAAN, KUALITAS LAYANAN, DAN POTONGAN HARGA
}

\author{
Muhammad Hilmi Oksadela1*; Ade Banani2; ${ }^{*}$ Rahab $^{3}$ \\ ${ }_{1}^{1}$ Magister Manajemen, Universitas Jenderal Soedirman, Indonesia \\ 2Magister Manajemen, Universitas Jenderal Soedirman, Indonesia \\ 3Magister Manajemen, Universitas Jenderal Soedirman, Indonesia \\ hilmi.oksadela@gmail.com
}

\begin{abstract}
Abstrak
Penelitian ini bertujuan untuk melihat apakah ada pengaruh antara kualitas layanan dan potongan harga melalui kepercayaan terhadap intensi menggunakan kembali jasa biro psikologi. Jumlah sampel yang digunakan sebanyak 50 sekolah menengah atas di Jakarta yang telah menggunakan jasa biro psikologi. Teknik pengambilan sampel yang digunakan adalah purposive sampling. Penelitian ini menggunakan pendekatan kuantitatif dengan teknik analisis jalur dengan software SPSS 16 dan Mplus 8.2. Hasil penelitian menunjukkan bahwa kualitas layanan dan potongan harga melalui kepercayaan berpengaruh positif terhadap intensi menggunakan kembali jasa biro psikologi. Terdapat pengaruh positif antara kualitas layanan dan potongan harga terhadap kepercayaan dan terdapat pengaruh positif antara kualitas layanan, potongan harga, dan kepercayaan terhadap intensi menggunakan kembali jasa biro psikologi. Implikasi yang diberikan pada penelitian ini diharapkan dapat memberikan manfaat bagi para penggiat bisnis biro psikologiuntuk lebih memperhatikan dalam hal penerapan kualitas layanan, potongan harga dan kepercayaan kepada konsumen.

Kata kunci: Intensi menggunakan kembali jasa psikologi, kualitas layanan, potongan harga, kepercayaan.
\end{abstract}

\begin{abstract}
This study aimed to see if there's any effect of service quality and discount through the trust as intervening variables towards intention to repurchase using services of psychological consultant. Researchers theorize that sevice quality and discount through the trust as intervening variables towards intention to repurchase using services of psychological consultant. This study used a quantitative approach with path analysis. Total 50 of unit sample Senior High School who have been used services of psychological consultant in Jakarta. Using SPSS 16 and Mplus 8.2 as software of analysis. The result showed the significant effect of sevice quality and discount through the trust as intervening variables towards intention to repurchase using services of psychological consultant. Hypothesis minor testing shows sevice quality and discount have a significantly effect toward trust, and sevice quality, discount, and trust have a significantly effect toward intention to repurchase using services of psychological consultant. Implication that was given at this research is expected to provide benefits for the business bureau of psychology in terms of the application of the quality of services, discounts for customers and trust to consumers.
\end{abstract}

Keywords: Intention to reused psycological service, service quality, discount, trust.

\section{PENDAHULUAN}

Psikologi merupakan salah satu bidang ilmu yang sangat dekat dengan kehidupan manusia, bahkan boleh dikatakan bahwa setiap ada manusia, disana ilmu psikologi itu berlaku (Koentjoro, 2005). Hal 
ini disebabkan karena psikologi merupakan ilmu yang mempelajari perilaku manusia. Semakin majunya kehidupan sosial yang ada di masyarakat memungkinkan adanya timbul berbagai masalah psikologis yang mungkin terjadi, hal ini menjadi perhatian besar bagi para konsultan yang bergerak di bidang psikologi.

Masalah psikologis yang dewasa ini sering muncul pada kaum remaja berupa bipolar disorder hal ini disebabkan oleh gangguan depresi, mania, atau hypomania (Marianti, 2018). Hal tersebut terjadi karena kurangnya perhatian dari orang sekitar terhadap perilaku remaja tersebut. Hal seperti inilah yang nantinya menjadi perhatian biro psikologi untuk menemukan dan memecahkan masalah yang telah terjadi.

Dengan berbagai permasalahan psikologis yang muncul serta berkembangnya ilmu psikologi di masyarakat maka kebutuhan akan jasa layanan psikologi semakin meningkat. Sesuai dengan hasil penelitian yang dinyatakan oleh Gunarsa (1992), bahwa semakin maraknya berbagai biro psikologi di kota besar menandakan bahwa masyarakat mulai mempercayai biro psikologi untuk mengukur aspek psikologis dalam diri pelanggan. Menurut data yang diperoleh Hirzithariqi (2009) ada banyak nama biro konsultasi psikologi yang berkembang. Tercatat di Jakarta ada 109 biro layanan psikologi, di Yogyakarta ada delapan biro layanan psikologi, di Bandung ada tujuh biro, dan masih banyak biro di kota kecil yang belum terjangkau.

Biro konsultasi psikologi sendiri merupakan suatu Lembaga yang bekerja untuk pemilik bisnis, pemerintah, sekolah dan organisasi lainnya. termasuk melakukan segala sesuatu dari membantu pengacara memilih juri dan bertindak sebagai saksi ahli dalam sengketa hukum, serta membantu perusahaan bisnis membuat program pelatihan karyawan dan desain produk baru. Kantor konsultasi psikologi juga melakukan penelitian di lapangan dan mengajar. Psikotes sebagai serangkaian layanan uji tes psikologi yang diberikan dengan tujuan mengungkap psikologis klien yang mana data tes tersebut bisa digunakan untuk berbagai kepentingan. Di dunia pendidikan, layanan psikotes diberikan dengan maksud untuk kepentingan akademik dan instansi pendidikan. Berbagai jenis layanan psikotes seperti tes minat bakat, intelegensi, kepribadian, dan gaya belajar diberikan pada unit sekolah dalam membantu siswa untuk dapat memaksimalkan potensi dan prestasi sekolah. Penerapan penjurusan sekolah siswa dengan psikotes akan membantu siswa tidak salah jurusan. Penjurusan siswa memasuki kelas IPA, IPS ataupun Bahasa, maupun penjurusan siswa pada saat akan memasuki jurusan perkuliahan nantinya. Tujuannya bagi siswa yaitu menemukan minat dan bakat siswa sesuai dengan jurusan yang dipilihnya.

Banyaknya biro psikologi yang beredar di seluruh Indonesia membuat peta persaingan bisnis semakin ketat. Banyak biro psikologi yang sudah lama berdiri mulai tergusur oleh adanya biro psikologi baru yang kompeten di bidangnya, begitupun sebaliknya ada beberapa biro psikologi baru yang sulit berkembang karena para klien lebih memilih untuk menggunakan kembali jasa biro psikologi yang sudah pernah mereka gunakan jasanya. Hal ini menjadi pertanyaan dan masalah yang menarik untuk diketahui, faktor apakah yang sebenarnya mempengaruhi klien untuk kembali menggunakan jasa biro psikologi. Tujuan dalam artikel ini adalah untuk menguji pengaruh kualitas layanan dan potongan harga melalui variabel mediasi kepercayaan terhadap intensi menggunakan kembali jasa biro psikologi. Ruang lingkup penelitian ini dibatasi untuk meneliti pengaruh kualitas layanan, potongan harga dimediasi variabel kepercayaan terhadap intensi menggunakan kembali jasa biro psikologi. Masalah dibatasi guna mengetahui faktor apa sajakah yang mempengaruhi 
konsumen untuk menggunakan kembali jasa biro psikologi. Variabel yang digunakan juga dibatasi menjadi, Intensi menggunakan kembali jasa biro psikologi pada penelitian ini dimana konsumen ingin dan memiliki maksud untuk menggunakan kembali jasa biro psikologi berdasarkan indikator perilaku, sasaran, situasi, dan waktu. Selanjutnya kualitas layanan merupakan penilaian konsumen dari pengguna jasa biro psikologi akan entitas kesempurnaan atau superioritas. Potongan harga dalam penelitian ini adalah potongan nilai jual yang diberikan penjual kepada konsumen. Kepercayaan dalam penelitian ini adalah perasaan tenang dari pelanggan dalam interaksinya dengan sebuah layanan jasa berdasarkan harapan pasti dari jaminan kepuasan, perhatian, dan kejujuran. Subjek penelitian yang diteliti adalah sekolah yang sudah pernah menggunakan jasa biro psikologi.

\section{TINJAUAN PUSTAKA DAN PERUMUSAN HIPOTESIS}

\section{Intensi Menggunakan Kembali}

Intensi adalah sebuah ciri yang dapat dijelaskan dari proses psikologi yang melingkupi referensi atau kaitannya pada suatu objek (Engel, Blackwell, Miniard, 1995). Selanjutnya, Pavlou (dalam, Hassan, 2011) mengemukakan bahwa intensi membeli merupakan kondisi dimana pelanggan hanya ingin dan bermaksud melakukan suatu transaksi pembelian dalam konteks penelitian ini merupakan pembelian atau penggunaan dari suatu jasa biro psikologi.

Intensi membeli menurut Engel dan Blackwell (1990) dikatakan sebagai proses rencana membeli, pelanggan akan tertarik untuk menggunakan modal dalam bentuk waktu ataupun juga energi dalam menggunakan suatu jasa psikologi. Intensi membeli adalah perilaku yang timbul dalam respon pada niat pembelian kembali yang mengacu pada keinginan pelanggan dalam keinginannya untuk membeli kembali (Assael, 1998).

Intensi adalah kecenderungan dari seseorang apabila ingin melakukan suatu perilaku, intensi dapat muncul dalam ukuran yang berbeda, intensi dalam jumlah besar dapat dikatakan probabilitas (Ajzen, Fishbein, 1975). Intensi digunakan untuk memprediksi faktor yang dapat mempengaruhi perilaku. Intensi adalah indikator seseorang dalam keinginannya untuk melihat seberapa kuat usaha yang dilakukan untuk memunculkan suatu perilaku (Ajzen, 1991). Intensi dapat memungkinan seseorang untuk melakukan suatu perilaku yang dalam penelitian ini adalah perilaku ingin menggunakan kembali jasa dari sebuah biro psikologi.

Selanjutnya, Assael juga menyebutkan bahwa intensi membeli merupakan fase terakhir dari sebuah proses intensi pembelian yang bertahap. Timbulnya kebutuhan pada suatu produk atau jasa memulai tahap dari fase ini (need arousal), lalu pengolahan informasi yang dilakukan pelanggan (consumer information processing), Dilanjutkan pemilahan produk atau jasa tersebut oleh pelanggan. Hasil dari pemilahan ini pada akhirnya akan menimbulkan suatu niat atau intensi untuk melakukan pembelian, sebelum pada akhirnya pelanggan melakukan pembelian sebenarnya (Assael, 1998).

Schiffman dan Kanuk (2008) mengatakan ada tiga model membeli dari pelanggan, yaitu: membeli percobaan, membeli ulang, dan membeli jangka panjang. Pada saat pelanggan menggunakan jasa yang dalam penelitian ini adalah biro psikologi, membeli percobaan adalah situasi pada pelanggan saat pertama kali menggunakan suatu jasa biro psikologi umumnya dalam 
jumlah paket tes psikologi yang lebih sedikit dari biasanya. Penggunaan jasa selanjutnya yang dilakukan oleh pelanggan yang didasarkan pada pengalaman sebelumnya, maka pembelian tersebut dapat dikatakan sebagai membeli ulangan. Membeli jangka panjang adalah pada saat pelanggan melakukan pembelian jasa tes psikologi secara berkelanjutan antar waktu.

\section{Kualitas Layanan}

Kualitas layanan dapat dikatakan sebagai suatu sikap dari adanya hasil dari perbandingan antara harapan kualitas jasa pelanggan dengan kinerja organisasi yang dalam konteks penelitian ini merupakan biro psikologi yang dialami oleh pelanggan (Usmara, 2008). Pengharapan atau ekspektasi pelanggan dapat mempengaruhi keputusan untuk menggunakan suatu jasa biro psikologi. Pelanggan akan memunculkan sebuah perilaku pada pemberi jasa berdasarkan harapan sebelumnya. Perilaku dan informasi dari biro jasa ini yang nantinya dapat mempengaruhi keinginan pelanggan untuk menggunakan kembali jasa biro psikologi. Kualitas dapat muncul dari apa yang dibutuhkan oleh pelanggan lalu berakhir pada apa yang dirasakan oleh pelanggan. Oleh sebab itu, persepsi kualitas yang baik tidak berdasarkan pada persepsi dari pihak penjual atau penyedia jasa, tapi didasari oleh persepsi pelanggan.

Persepsi pelanggan pada kualitas adalah perilaku keseluruhan atas keunggulan pada suatu jasa (Kotler, 1998). Gale dan Buzell (1989); Band (1989) dalam Gaspersz (1997) mendukung bahwa yang dikatakan dengan kualitas adalah sebuah perspektif dari pelanggan. Krajewski dan Ritzman (1990) juga mengatakan hal yang sama yaitu membedakan kualitas berdasarkan persepsi produsen dan pelanggan. Berdasarkan persepsi produsen, kualitas merupakan kesesuaian pada spesifikasi, hal ini memberikan biro psikologi toleransi tertentu yang dibedakan pada setiap atribut dari setiap bagian yang dihasilkan. Berdasarkan pada persepsi pelanggan, kualitas merupakan sebuah nilai, seberapa baik atau buruknya suatu layanan dari jasa yang diberikan biro psikologi menyediakan tujuan pada tingkat harga yang bersedia dibayar oleh pelanggan dalam menilai kualitas.

Kepercayaan pelanggan berkaitan dengan kualitas layanan yang didapatkan oleh pelanggan tersebut. Dapat dikatakan kualitas layanan yang baik tidak berdasarkan pada sudut pandang pihak penyedia jasa, melainkan dari pandangan pelanggan. Pelanggan menggunakan atau menikmati jasa biro psikologi, sehingga pelangganlah yang dapat menentukan kualitas suatu layanan. Selanjutnya kualitas layanan didefinisikan sebagai harapan dan keinginan pelanggan (Parasuraman et al. dalam Teas, 1993).

Dalam mengukur kualitas layanan, biro psikologi seringkali hanya mengukur persepsi berdasarkan layanan yang dirasakan pelanggan saja. Biro psikologi tidak mengikutsertakan harapan pelanggan dalam pengukuran kualitas layanan. Teori ini berdasarkan pada apa yang dikatan oleh Cronin dan Taylor dalam Parasuraman dkk (1993) yang menyebutkan bahwa mengukur harapan pelanggan merupakan hal yang tidak penting dalam meneliti kualitas layanan. Cronin dan Taylor mengatakan pengukuran persepsi atas layanan jasa yang dirasakan oleh pelanggan sudah dianggap memenuhi dalam pengukuran kualitas layanan. 


\section{Potongan Harga}

Potongan harga adalah istilah yang dibebankan kepada suatu jasa yang nilainya telah berkurang dari nilai aslinya untuk kepentingan promosi (Kotler dan Armstrong, 2012). Potongan harga biasanya diberikan sebagai benefit saat pelanggan ingin menggunakan kembali suatu jasa psikologi, pemberian potongan harga ini juga bisa bersifat persuasif sebagai cara untuk mempertahankan hubungan baik antara penyedia jasa dan pelanggan biro psikologi. Dalam menetapkan potongan harga tidaklah mudah, ada beberapa proses yang harus dijalankan. Hal ini dilakukan agar biro psikologi mendapatkan keuntungan. Beberapa proses yang harus dilakukan oleh suatu biro psikologi dalam menetapkan potongan harga suatu layanan jasa adalah melalui daftar harga yang telah diberikan oleh penyedia jasa biro psikologi ataupun proses menegosiasi dengan pelanggan. Promosi penjualan merupakan kegiatan pemasaran selain penjualan pribadi, periklanan, dan publisitas yang mendorong pembelian konsumen serta efektifitas penyalur (Boyd, et al., 2000). Biro psikologi menggunakan promosi penjualan konsumen (consumer sales promotion) yang berbeda untuk layanan jasa baru. Untuk layanan jasa yang baru, biro psikologi memberikan gambaran layanan yang akan diberikan. Penerapan promosi penjualan yang digunakan biro psikologi dalam persaingan harga menggunakan potongan harga yang dapat menarik perhatian pelanggan dalam keinginan untuk menggunakan kembali jasa biro psikologi dalam periode waktu tertentu sesuai dengan kebijakan biro psikologi tersebut. Dalam penelitian ini yang menjadi fokus bahasan adalah potongan harga.

Tjiptono (1997) mengatakan bahwa potongan harga adalah sesuatu yang diberikan penyedia jasa kepada pelanggan sebagai wujud penghargaan atas aktivitas tertentu dari penggunaan jasa yang menyenangkan bagi biro psikologi. Gitosudarmo (2000) potongan harga merupakan harga yang lebih rendah dari yang seharusnya dibayarkan didasari kepada beberapa hal yaitu waktu pembayaran yang lebih awal, tingkat serta jumlah pembelian dan pembelian pada musim tertentu. Kotler dan Armstrong (2008) mengatakan bahwa potongan harga merupakan pengurangan harga langsung terhadap suatu penggunaan jasa yang ditawarkan kepada pelanggan dalam periode tertentu.

Kebanyakan pelanggan dari biro psikologi merasa senang apabila diberikan potongan harga yang besar. Potongan harga yang diberikan dalam konteks jasa pada biro psikologi tanpa menurunkan kualitas dari pelayanannya terhadap pelanggan, penyedia jasa biro psikologi akan memberikan beberapa pilihan layanan yang akan didapatkan dengan potongan harga yang disesuaikan. Potongan harga yang besar tidak selalu potongan harga yang murah atau terjangkau, akan tetapi sebuah harga yang dirasakan pantas oleh pelanggan saat melakukan transaksi jual beli. Pelanggan berfikir apabila potongan harga yang diberikan oleh penyedia jasa masih tergolong cukup mahal maka layanan pada biro psikologi itu baik, namun jika potongan harga yang diberikan oleh biro psikologi jauh lebih murah maka pelanggan akan merasa curiga dan menganggap bahwa layanan dari biro psikologi tersebut kurang baik (Sundalangi et. al., 2014)

Sutisna (2001) menambahkan bahwa potongan harga merupakan pemotongan harga yang tadinya normal menjadi sedikit lebih murah dan biasa terjadi pada saat tertentu. Untuk menarik pelanggan pengguna jasa biro psikologi menggunakan pilihan jasa yang baru maka biro psikologi biasanya menerapkan pemotongan harga hal ini juga dapat dilaksanakan apabila ingin menarik pelanggan lama untuk kembali menggunakan jasa yang kali ini dalam jumlah yang lebih banyak, 
pemotongan harga bisa juga juga dilakukan untuk kembali meyakinkan pelanggan untuk tetap menggunakan layanan jasa yang lama. Sutisna berpendapat pada pihak penyedia produk atau jasa, pengadaan potongan harga dapat dilakukan demi mencapai target maksimal penjualan (Sutisna, 2001).

Penjual sudah seharusnya menggunakan kata seperti "sale" atau "special" apabila ingin memberikan potongan harga, maka pelanggan tidak akan beranggapan bahwa pemotongan harga tersebut dilakukan karena kurang baiknya kualitas jasa yang dijual dan percaya jika pemotongan harga tersebut dilakukan hanya dalam waktu yang sementara (Faryabi, 2012).

\section{Kepercayaan}

Kepercayaan merupakan faktor yang dapat digunakan untuk mempengaruhi keinginan pelanggan untuk kembali membeli atau menggunakan produk atau jasa. Kepercayaan juga dapat digunakan sebagai kunci untuk menjaga komitmen dari pelanggan (Morgan dan Hunt (1994) dalam Jasfar, 2012). kepercayaan adalah persepsi pelanggan akan ketetapan berdasarkan pada pengalaman yang dirasakan. Selain itu, rasa aman pelanggan dalam jual beli akan suatu produk atau jasa berdasarkan pada harapan yang sifatnya tetap dari kehandalan dan intensi merek (Costabile (1998) dalam Ferrinadewi, 2008).

Kepercayaan adalah faktor psikologi ketika individu menerima apa adanya didasari dengan harapan terhadap sikap yang baik dari orang lain (Rousseau et. al., 1998). Kepercayaan juga dapat diartikan sebagai ketersediaan salah satu pihak dalam menerima resiko berdasarkan pada tindakan dari pihak lain dengan harapan bahwa pihak tersebut akan melakukan sesuatu yang penting kepada pihak yang mempercayainya, diluar dari kemampuan untuk melihat dan mengendalikan sebuah tindakan dari pihak yang dipercaya (Mayer et al, 1995).

Kepercayaan membawa anggapan bahwa dirinya akan mendapatkan apa yang diinginkan pada diri orang lain, bukan menemukan apa yang ia cemaskan. Kepercayaan membuat seseorang bersedia melakukan sesuatu karena orang tersebut percaya bahwa seseorang yang dipercayakan akan memberikan timbal balik seperti apa yang ia harapkan seperti perkataan, perjanjian, atau pernyataan dari orang lain yang dapat dipercayakan (Barnes, 2003).

\section{Perumusan Hipotesis}

Pada penelitian sebelumnya terdapat beberapa perbedaan dari hasil penelitiannya. Penelitian yang dilakukan oleh Adiatma \& Sudrajat (2013); Auh \& Seigyoung (2005); Sahin (2011), Etamadifard (2013), dan Elliot (2012) ditemukan bahwa kualitas layanan berpengaruh terhadap kepercayaan. sedangkan hasil penelitian dari Mahlangu et al. (2013) menyatakan bahwa kualitas layanan tidak memiliki pengaruh terhadap kepercayaan pelanggan.

\section{$\mathrm{H}_{1}$ : Kualitas layanan berpengaruh positif terhadap kepercayaan menggunakan kembali jasa biro psikologi.}

Penelitian yang dilakukan oleh Andilala et al. (2018); Murwatiningsih \& Apriliani (2013) menunjukkan hasil bahwa potongan harga tidak berpengaruh signifikan terhadap kepercayaan. Penelitian lain juga pernah dilakukan oleh Sitorus (2015) Hasil menunjukkan bahwa potongan harga berpengaruh secara signifikan terhadap kepercayaan menggunakan koperasi dari Siswa SMK. 


\section{$\mathrm{H}_{2}$ : Potongan harga berpengaruh positif terhadap kepercayaan menggunakan kembali jasa} biro psikologi.

Biner dalam Suh \& Pedersen (2010); Olorunniwo et al. (2006); Hong dan Brahmana (2016) menyatakan bahwa terdapat efek langsung antara kualitas layanan perilaku intensi membeli.

$\mathrm{H}_{3}$ : Kualitas layanan berpengaruh positif terhadap intensi menggunakan kembali jasa biro psikologi.

Ghassani (2017) menunjukkan bahwa terdapat ada pengaruh signifikan antara kualitas produk dan potongan harga terhadap niat membeli ulang. Hasil penelitian Mirabi et al. (2015) menyimpulkan bahwa variabel kualitas merek, kualitas produk, dan iklan memiliki pengaruh terhadap niat pembelian ulang, sedangkan kemasan dan potongan harga tidak memiliki pengaruh terhadap niat pembelian ulang. Sebagian besar konsumen lebih mementingkan kualitas produk tanpa melihat kemasan dan potongan harga.

$\mathrm{H}_{4}$ : Potongan harga berpengaruh positif terhadap intensi menggunakan kembali jasa biro psikologi.

Pada penelitian yang dilakukan oleh Lodan \& Anshori (2013); Irwanda dan Hati (2014) dikatakan hasil penelitian menunjukkan trust berpengaruh terhadap intensi pembelian konsumen secara online, baik secara simultan maupun parsial. kepercayaan yang dirasakan terhadap internet vendor memberikan efek positif yang membuat pelanggan tetap ingin berbelanja.

$\mathrm{H}_{5}$ : Kepercayaan berpengaruh positif terhadap intensi menggunakan kembali jasa biro psikologi.

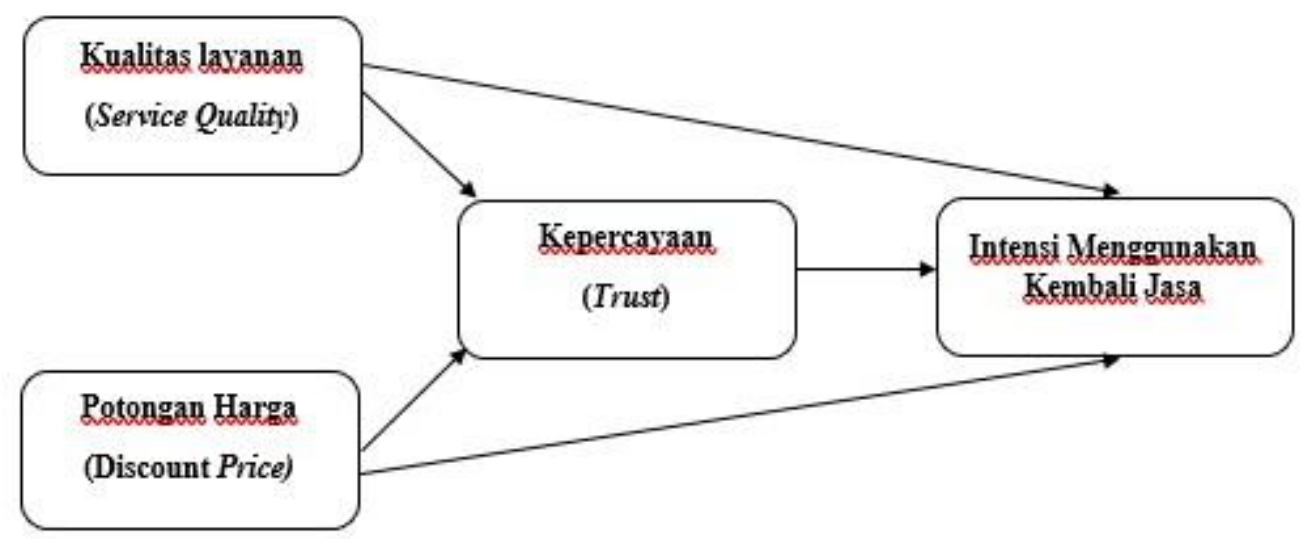

Gambar 1. Model Penelitian

\section{METODE PENELITIAN}

Jenis penelitian ini adalah penelitian kuantitatif, dimana data penelitiannya berupa angka disertakan dengan pengumpulan dan pengukuran data dengan tujuan untuk menguji hipotesis dan menjawab pertanyaan yang menyangkut tujuan penelitian. Penelitian ini merupakan jenis penelitian kausal. Penggunaan rancangan penelitian kausal dalam penelitian ini disesuaikan dengan tujuan penelitian, yakni mengetahui pengaruh kualitas layanan dan potongan harga melalui variabel mediasi kepercayaan terhadap intensi menggunakan kembali jasa biro psikologi. 
Dalam penelitian ini tidak ada perlakuan khusus pada subyek penelitian, fakta yang terjadi dan pengalaman dari subjek selama penelitian dikaji secara empiris. Berdasarkan kepada uraian tersebut, penelitian menggunakan pendekatan kuantitatif dengan metode kausal, dan rancangan penelitian ini memodelkan kualitas layanan (X1) dan potongan harga (X2) sebagai variabel bebas dan kepercayaan (Y) serta intensi menggunakan kembali jasa biro psikologi (Z) sebagai variabel terikat.

Metode pengumpulan data yang dilakukan melalui penyebaran kuesioner yaitu dengan memberikan daftar pernyataan tertulis yang telah disusun secara sistematis kepada responden penelitian. Nonprobability sampling digunakan sebagai teknik sampling pada penelitian ini, yakni tidak semua anggota populasi mempunyai kesempatan yang sama untuk menjadi sampel, purposive sampling digunakan sebagai teknik pengambilan sampel yakni kuesioner diberikan kepada sekolah yang memiliki karakteristik yang sesuai dengan tujuan penelitian yaitu sekolah yang sudah pernah menggunakan jasa biro psikologi sebelumnya.

Skala pengukuran yang digunakan dalam kuesioner ini skala Likert dengan menggunakan rentang skor 1-5. Penelitian ini memilih Sekolah Menengah Atas di daerah Jakarta Selatan sebagai populasi penelitian sebanyak 116 sekolah. Karakteristik sampel yang dipilih adalah sekolah yang pernah menggunakan jasa biro psikologi. Unit sampelnya merupakan guru bimbingan konseling yang ada pada sekolah tersebut. Penelitian ini bersifat B to C yakni Business to Consumer dimana bisnis yang dilakukan merupakan pelayanan jasa kepada konsumen perorangan atau grup secara langsung. Dengan kata lain, bisnis yang Anda lakukan berhubungan langsung dengan konsumen bukan perusahaan atau bisnis lainnya. Menurut Roscoe (1975) ukuran sampel penelitian korelasional lebih dari 30 dan kurang dari 500 adalah tepat. Dalam penelitian multivariate ukuran sampel sebaiknya lebih banyak 10 kali lipat dari jumlah variabel penelitian sehingga sampel yang digunakan sebanyak 50 sekolah. Uji validitas pada penelitian ini menggunakan korelasi bivariate pearson atau product moment jika $r$ hitung $>r$ tabel. Teknik analisis data yang digunakan adalah teknik analisis jalur.

\section{HASIL PENELITIAN DAN PEMBAHASAN}

Hasil penelitian menunjukkan terdapat pengaruh yang signifikan antara kualitas layanan dan potongan harga terhadap kepercayaan. Diperoleh $\mathrm{R}^{2}$ sebesar 0.737 atau $73.7 \%$. Artinya proporsi varians dari kepercayaan yang dijelaskan oleh kualitas layanan dan potongan harga dalam penelitian ini adalah sebesar 73.7\%, sedangkan 26.3\% lainnya dipengaruhi oleh variabel lain di luar penelitian ini. Selanjutnya, terdapat pengaruh signifikan antara kualitas layanan, potongan harga, dan kepercayaan terhadap intensi menggunakan kembali jasa biro psikologi. Diperoleh $\mathrm{R}^{2}$ sebesar 0.781 atau $78.1 \%$. Artinya proporsi varians dari intensi menggunakan kembali jasa biro psikologi yang dijelaskan oleh kualitas layanan, potongan harga dan kepercayaan dalam penelitian ini adalah sebesar 78.1\%, sedangkan 21.9\% lainnya dipengaruhi oleh variabel lain di luar penelitian ini.

Nilai 0.625 adalah koefisien regresi kualitas layanan terhadap kepercayaan (dalam SPSS dinotasikan dengan Beta), nilai 0.348 adalah koefisien regresi potongan harga terhadap kepercayaan, nilai 0.432 adalah koefisien regresi kualitas layanan terhadap intensi menggunakan jasa, nilai 0.247 adalah koefisien regresi potongan harga terhadap intensi menggunakan jasa, dan nilai 0.315 adalah koefisien regresi kepecayaan terhadap intensi menggunakan jasa. 
Nilai 0.263 merupakan nilai residu antara kualitas layanan dan potongan harga terhadap kepercayaan. Sementara itu, nilai 0.219 merupakan nilai residu antara kualitas layanan, potongan harga, dan kepercayaan terhadap intensi menggunakan jasa. Nilai Residu merupakan nilai yang menunjukkan adanya korelasi yang disebabkan oleh variabel lain diluar penelitian.

Untuk nilai Uji Fit peneliti melihat melalui nilai dari RMSEA model tersebut, dan nilai RMSEA model adalah 0.0000 yakni apabila nilai RMSEA dari model tersebut dibawah atau sama dengan 0.05 yang merupakan indeks untuk model tersebut dapat diterima atau menunjukkan Close Fit dari model tesebut berdasar pada degree of freedom (Bowne dan Cudeck, dalam Ferdinand, 2000).

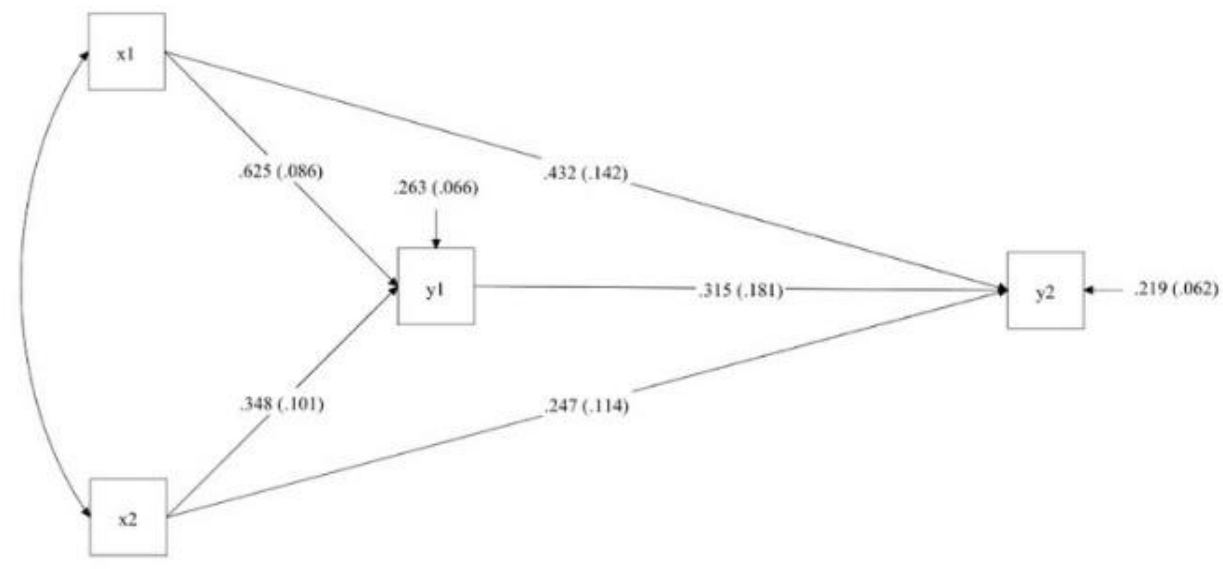

Gambar 2. Model Path Analysis dengan Mplus 8.2

Tabel 1. Hasil Pengujian Hipotesis

\begin{tabular}{lccc}
\hline \multicolumn{1}{c}{ HIPOTESIS } & $\begin{array}{c}\text { STANDARDIZED } \\
\text { COEFFICIENTS } \\
\text { BETA }\end{array}$ & SIG. & KESIMPULAN \\
\hline $\begin{array}{l}\text { Kualitas layanan } \\
\text { bepengaruh positif pada } \\
\text { kepercayaan }\end{array}$ & .625 & .000 & Terdukung \\
$\begin{array}{l}\text { Potongan harga } \\
\text { berpengaruh positif } \\
\text { terhadap kepecayaan }\end{array}$ & .348 & .000 & Terdukung \\
$\begin{array}{l}\text { Kualitas layanan } \\
\text { berpengaruh positif } \\
\text { terhadap intensi } \\
\text { menggunakan jasa } \\
\begin{array}{l}\text { Potongan harga } \\
\text { bepengaruh positif } \\
\text { terhadap intensi } \\
\text { menggunakan jasa }\end{array}\end{array}$ & .432 & .001 & Terdukung \\
$\begin{array}{l}\text { Kepercayaan } \\
\text { berpengaruh positif } \\
\text { terhadap intensi } \\
\text { menggunakan jasa }\end{array}$ & .247 & & Terdukung \\
\hline
\end{tabular}


Sumber: Data primer terolah, 2018

Berdasarkan pada tabel 1 hasil penelitian hipotesis maka dapat disimpulkan bahwa variabel kualitas layanan dan potongan harga memiliki pengaruh positif terhadap kepercayaan konsumen. Kualitas layanan, potongan harga, dan kepercayaan memiliki pengaruh positif terhadap intensi menggunakan kembali jasa biro psikologi. Kepercayaan mampu memediasi pengaruh antara kualitas layanan terhadap intensi menggunakan kembali jasa biro psikologi. Kepercayaan mampu memediasi pengaruh antara potongan harga terhadap intensi menggunakan kembali jasa biro psikologi.

Kemudian, untuk menilai ketetapan penggunaan model analisis jalur yaitu untuk mengetahui apakah model analisis jalur sudah sesuai dengan data yang diperoleh maka dilakukan pengujian model fit. Pada tingkat signifikansi 5\% didapatkan RMSEA $<0.05$. Hal ini menunjukkan bahwa model analisis jalur fit (sesuai) dengan data.

Koefisien regresi masing-masing variabel independen kualitas layanan dan potongan harga terhadap kepercayaan dapat dilihat dalam tabel berikut:

\section{Tabel 2. Koefisien regresi variabel independen}

\section{Coefficients ${ }^{\mathrm{a}}$}

\begin{tabular}{|c|c|c|c|c|c|}
\hline \multirow[t]{2}{*}{ Model } & \multicolumn{2}{|c|}{ Unstandardized Coefficients } & \multirow{2}{*}{$\begin{array}{c}\text { Standardized } \\
\text { Coefficients } \\
\text { Beta }\end{array}$} & \multirow[t]{2}{*}{$\mathrm{t}$} & \multirow[t]{2}{*}{ Sig. } \\
\hline & B & Std. Error & & & \\
\hline (Constant) & .680 & .309 & & 2.205 & .032 \\
\hline Kualitas Layanan & .642 & .090 & .625 & 7.144 & .000 \\
\hline Potongan Harga & .200 & .050 & .348 & 3.981 & .000 \\
\hline
\end{tabular}

a. Dependent Variable: Kepercayaan

Sumber: Data primer terolah, 2018

Berdasarkan tabel 2, dapat diketahui bahwa terdapat dua variabel yang signifikan terhadap kepercayaan konsumen.

Interpretasi pada diskusi penelitian dinyatakan dalam satuan logit. Berdasarkan hasil penelitian pada proporsi varian untuk masing-masing variabel independen yang dilakukan oleh peneliti, diketahui bahwa sumbangan variabel kualitas layanan diperoleh nilai koefisien regresi sebesar 0.625 atau $62.5 \%$ dengan Sig. sebesar 0.000 (Sig. < 0.05), dengan demikian $\mathrm{H}_{01}$ yang menyatakan tidak ada pengaruh yang signifikan dari kualitas layanan terhadap kepercayaan ditolak. Artinya, kualitas layanan memiliki pengaruh yang signifikan terhadap kepercayaan.

Pada variabel potongan harga diperoleh nilai koefisien regresi sebesar 0.348 atau $34.8 \%$ dengan Sig. sebesar 0.000 (Sig. $<0.05$ ), dengan demikian $\mathrm{H}_{02}$ yang menyatakan tidak ada pengaruh yang signifikan dari potongan harga terhadap kepercayaan ditolak. Artinya, potongan harga memiliki pengaruh yang signifikan terhadap kepercayaan.

Koefisien regresi masing-masing variabel independen kualitas layanan, potongan harga dan kepercayaan terhadap intensi menggunakan kembali jasa biro psikologi dapat dilihat dalam tabel berikut: 
Tabel 3. Koefisien regresi variabel independen

\begin{tabular}{|c|c|c|c|c|c|}
\hline \multicolumn{6}{|c|}{ Coefficientsa } \\
\hline \multirow[t]{2}{*}{ Model } & \multicolumn{2}{|c|}{ Unstandardized Coefficients } & \multirow{2}{*}{$\begin{array}{c}\text { Standardized } \\
\text { Coefficients } \\
\text { Beta }\end{array}$} & \multirow[t]{2}{*}{$\mathrm{t}$} & \multirow[t]{2}{*}{ Sig. } \\
\hline & $\mathrm{B}$ & Std. Error & & & \\
\hline (Constant) & .195 & .302 & & .646 & .522 \\
\hline Kualitas Layanan & .449 & .121 & .432 & 3.713 & .001 \\
\hline Potongan Harga & .144 & .054 & .247 & 2.651 & .011 \\
\hline Kepercayaan & .318 & .136 & .315 & 2.341 & .024 \\
\hline
\end{tabular}

a. Dependent Variable: Intensi Menggunakan Jasa

Sumber: Data primer terolah, 2018

Berdasarkan tabel 3, dapat diketahui bahwa ketiga variabel signifikan terhadap intensi menggunakan kembali jasa biro psikologi.

Berdasarkan hasil penelitian pada proporsi varian untuk masing-masing variabel independen yang dilakukan oleh peneliti, diketahui bahwa sumbangan variabel kualitas layanan: diperoleh nilai koefisien regresi sebesar 0.432 atau 43.2\% dengan Sig. sebesar 0.001 (Sig. < 0.05), dengan demikian $\mathrm{H}_{01}$ yang menyatakan tidak ada pengaruh yang signifikan dari kualitas layanan terhadap intensi menggunakan kembali jasa biro psikologi ditolak. Artinya, kualitas layanan memiliki pengaruh yang signifikan terhadap intensi menggunakan kembali jasa biro psikologi.

Pada variabel potongan harga diperoleh nilai koefisien regresi sebesar 0.247 atau $24.7 \%$ dengan Sig. sebesar 0.011 (Sig. < 0.05), dengan demikian $\mathrm{H}_{02}$ yang menyatakan tidak ada pengaruh yang signifikan dari potongan harga terhadap intensi menggunakan kembali jasa biro psikologi ditolak. Artinya, potongan harga memiliki pengaruh yang signifikan terhadap intensi menggunakan kembali jasa biro psikologi.

Selanjutnya pada variabel kepercayaan diperoleh nilai koefisien regresi sebesar 0.315 dengan Sig. sebesar 0.024 (Sig. < 0.05), dengan demikian $\mathrm{H}_{03}$ yang menyatakan tidak ada pengaruh yang signifikan dari kepercayaan terhadap intensi menggunakan kembali jasa biro psikologi ditolak. Artinya, kepercayaan memiliki pengaruh yang signifikan terhadap intensi menggunakan kembali jasa biro psikologi.

Bagaimanapun, ketidaksesuaian atau perbedaan yang dihasilkan dari penelitian ini dengan hasil penelitian terdahulu mungkin disebabkan oleh beberapa faktor penting seperti sampling error, jumlah sampel, latar belakang pendidikan, serta hal lain yang tidak ikut diteliti dalam penelitian ini. Selain itu, latar belakang kultur yang berbeda antara penelitian terdahulu dan penelitian ini juga menyebabkan terjadinya perbedaan hasil.

\section{PEMBAHASAN}

\section{Pengaruh kualitas layanan terhadap kepercayaan menggunakan kembali jasa biro psikologi}

Hasil penelitian menunjukkan kualitas layanan merupakan faktor penting untuk konsumen dalam memilih dan mempercayakan suatu biro psikologi dalam pelaksanaan tes psikologi di sekolah 
mereka. Dengan baiknya kualitas layanan dalam pelaksanaan tes psikologi seperti yang terdapat dalam indikator yang paling linear yaitu jaminan, dimana konsumen merasa bahwa apabila psikolog berani menjamin target yang diminta dan kualitas dari layanan yang akan diberikan maka para pelanggan dapat mempercayakan anak didiknya untuk dilihat bagaimanakah hasil dari tes psikologi yang dilakukan baik dari aspek intelegensi, gaya belajar, maupun kepribadian anak tersebut. Hasil penelitian menunjukkan kesesuaian dengan hipotesis penelitian yang menyatakan kualitas layanan berpengaruh positif terhadap kepercayaan konsumen. Setiap peningkatan kualitas layanan akan meningkatkan kepercayaan konsumen adalah sebesar 62,5 persen.

Menurut Kotler (1997) mengatakan bahwa kualitas harus dimulai dari kebutuhan pelanggan dan berakhir pada persepsi pelanggan. Berarti citra kualitas yang baik bukan dilihat dari persepsi pihak penyedia jasa, melainkan berdasarkan persepsi para pelanggan. Apabila pelanggan beranggapan bahwa kualitas layanan baik maka akan menimbulkan kepercayaan pada pelanggan tersebut. Persepsi pelanggan terhadap kualitas merupakan perilaku menyeluruh atas keunggulan suatu jasa. Parasuraman et al. dalam Teas (1993) menambahkan persepsi akan kualitan layanan sebagai kepercayaan pelanggan yang berhubungan dengan jasa yang diterima. Hal ini berarti citra kualitas jasa yang baik bukanlah berdasarkan sudut pandang atau persepsi pihak penyedia jasa, melainkan berdasarkan dari pandangan pelanggan.

Hal ini sesuai dengan penelitian Auh \& Seigyoung (2005) mengemukakan bahwa secara empiris bahwa persepsi kualitas layanan yang prima oleh konsumen berpengaruh terhadap kepercayaan secara signifikan. Penelitian lain oleh Sahin (2011), Etamadifard (2013), dan Elliot (2012) menyatakan bahwa service quality memiliki pengaruh terhadap trust secara signifikan.

\section{Pengaruh potongan harga terhadap kepercayaan menggunakan kembali jasa biro psikologi}

Hasil penelitian menunjukkan potongan harga merupakan faktor penting untuk konsumen dalam memilih dan mempercayakan suatu biro psikologi dalam pelaksanaan tes psikologi di sekolah mereka. Sesuai dengan indikator yang paling linear dari item potongan harga yakni frekuensi dan jenis potongan harga dimana pelanggan ditawarkan pilihan berupa potongan harga yang menarik dengan paket layanan yang sesuai dengan harga, hal ini lebih menarik perhatian pelanggan disbanding langsung diberikan harga yang murah. Dengan adanya potongan harga dalam penawaran untuk pelaksanaan tes psikologi, konsumen merasa bahwa harga yang diperoleh pantas sehingga dapat mempercayakan anak didiknya untuk dilihat bagaimanakah hasil dari tes psikologi yang dilakukan baik dari aspek intelegensi, gaya belajar, maupun kepribadian anak tersebut. Berbeda apabila dari awal diberikan harga yang tergolong murah, konsumen mungkin akan merasa kurang percaya dan beranggapan bahwa kualitas dari biro psikologi tersebut kurang baik sehingga menawarkan harga yang murah. Hasil penelitian menunjukkan kesesuaian dengan hipotesis penelitian yang menyatakan potongan harga berpengaruh positif terhadap kepercayaan konsumen. Setap peningkatan dari potongan harga akan meningkatkan kepercayaan konsumen adalah sebesar 34.8 persen.

Potongan potongan harga umumnya dipakai untuk mendorong penggunaan produk baru, untuk membujuk pengguna lama agar membeli lebih banyak, atau untuk meyakinkan pengguna untuk mencoba produk atau jasa yang telah lama ada (Sutisna, 2001). Menurut Faryabi (2012) retiler harus memastikan bahwa kata-kata seperti "sale" atau "special" yang digunakan pada diskon, 
sehingga konsumen percaya bahwa diskon hanya untuk jangka waktu sementara dan tidak menganggap hal itu sebagai alasan untuk rendahnya kualitas produk.

Hasil ini sejalan dengan penelitian yang dilakukan oleh Sitorus (2015) yang menunjukkan hasil bahwa potongan harga berpengaruh secara signifikan terhadap kepercayaan menggunakan koperasi dari Siswa SMK. Akan tetapi hasil penelitian ini tidak sejalan dengan penelitian yang dilakukan oleh Andilala et al. (2018) menunjukkan hasil bahwa potongan harga dan persepsi reputasi tidak berpengaruh signifikan terhadap kepercayaan.

\section{Pengaruh kualitas layanan terhadap intensi menggunakan kembali jasa biro psikologi}

Hasil penelitian menunjukkan kualitas layanan merupakan faktor penting untuk konsumen dalam memilih dan menggunakan suatu biro psikologi dalam pelaksanaan tes psikologi di sekolah mereka. Berdasarkan indikator kualitas layanan yang linear yakni empati, pelanggan mengutamakan kualitas pelayanan yang memberikan kenyamanan kepada pelanggannya. Dengan baiknya kualitas layanan dan kenyamanan dalam pelaksanaan tes psikologi yang dilaksanakan, konsumen akan merasa tertarik dan berfikir bahwa biro tersebut dapat dipercaya untuk kembali digunakan dalam mengetest anak didiknya untuk dilihat bagaimanakah hasil dari tes psikologi yang dilakukan baik dari aspek intelegensi, gaya belajar, maupun kepribadian anak tersebut. Hasil penelitian menunjukkan kesesuaian dengan hipotesis penelitian yang menyatakan kualitas layanan berpengaruh positif terhadap intensi menggunakan kembali jasa biro psikologi pada konsumen. Setiap peningkatan dari kualitas layanan akan meningkatkan intensi menggunakan kembali jasa biro psikologi pada konsumen adalah sebesar 43.2 persen.

Usmara (2008) menyatakan bahwa kualitas pelayanan digambarkan sebagai suatu sikap dari hasil perbandingan pengharapan kualitas jasa konsumen dengan kinerja perusahaan yang dirasakan konsumen. Sikap mempengaruhi keputusan untuk membeli atau menggunakan suatu jasa karena adanya pengharapan atau ekspektasi konsumen. Selanjutnya konsumen membentuk suatu perilaku tentang pemberi jasa berdasarkan pengharapan mereka sebelumnya mengenai informasi perusahaan dan perilaku ini mempengaruhi keinginan mereka untuk menggunakan jasa biro psikologi. Biner dalam Suh \& Pedersen (2010) juga menyatakan bahwa terdapat efek langsung antara service quality dan behavioral intention. Hal ini juga didukung oleh Olorunniwo et al. (2006) menyatakan bahwa ada pengaruh service quality terhadap behavioral intention pada perusahaan jasa.

Hasil ini sejalan dengan penelitian yang dilakukan oleh Penelitian yang dilakukan oleh Hong dan Brahmana (2016) yang mengatakan bahwa terdapat pengaruh secara struktural antara service quality, perceived value, customer satisfaction, dan repurchase intention. Penelitian lain yang menunjukkan hasil yang senada dilakukan juga oleh Sylvyana (2006) yang mengatakan bahwa Faktor kualitas pelayanan mempunyai pengaruh signifikan terhadap intensi meregistrasi ulang.

\section{Pengaruh potongan harga terhadap Intensi menggunakan kembali jasa biro psikologi}

Hasil penelitian menunjukkan potongan harga merupakan faktor penting untuk konsumen dalam memilih dan menggunakan suatu biro psikologi dalam pelaksanaan tes psikologi di sekolah mereka. Berdasarkan indikator potongan harga yang linear yakni frekuensi dan jenis potongan harga terlihat bahwa pelanggan lebih menyukai keberadaan potongan harga. Dengan adanya potongan 
harga dalam penawaran untuk pelaksanaan tes psikologi, konsumen merasa bahwa harga yang diperoleh cukup baik sehingga akan memilih menggunakan kembali jasa dari biro psikologi tersebut. Promosi dari potongan harga yang diberikan dapat menarik atensi dan juga intensi bagi para konsumen untuk kembali menggunakan jasa biro psikologi tersebut. Hasil penelitian menunjukkan kesesuaian dengan hipotesis penelitian yang menyatakan potongan harga berpengaruh positif terhadap intensi menggunakan kembali jasa biro psikologi pada konsumen. Setiap peningkatan dari potongan harga akan meningkatkan intensi menggunakan kembali jasa biro psikologi pada konsumen adalah sebesar 24.7 persen.

Potongan harga merupakan sebuah nilai yang menyatakan sejumlah uang yang dibebankan atas sebuah produk maupun jasa (Kotler dan Armstrong, 2012). Dalam menetapkan potongan harga tidaklah mudah, ada beberapa proses yang harus dijalankan. Hal ini dilakukan supaya perusahaan mendapatkan keuntungan. Beberapa proses yang harus dilakukan oleh suatu biro psikologi dalam menetapkan potongan harga suatu produk. Sundalangi et. al., (2014) menambahkan bahwa para konsumen tertarik untuk mendapatkan potongan harga yang pantas. Potongan harga yang pantas bukan berarti potongan harga yang murah dan terjangkau, namun nilai yang dipersepsikan pantas pada saat transaksi dilakukan.

Hasil ini senada dengan penelitian yang dilakukan oleh Nguyen \& Gizaw (2014) yang mengatakan bahwa dari hasil penelitian dapat disimpulkan bahwa terdapat pengaruh yang signifikan antara variable kualitas merek, persepsi konsumen, perilaku konsumen, potongan harga, dan demografi terhadap niat pembelian ulang konsumen. Penelitian lain yang menunjukkan hal senada dilakukan oleh Prawira dan Yasa (2013) yang mengatakan bahwa terdapat pengaruh yang signifikan antara variabel kualitas produk, citra merek dan persepsi potongan harga terhadap minat beli konsumen. Akan tetapi, hasil penelitian ini tidak senada dengan hasil penelitian yang dilakukan oleh Ghassani (2017) yang menunjukkan bahwa terdapat ada pengaruh signifikan antara kualitas produk dan potongan harga terhadap niat membeli ulang.

\section{Pengaruh Kepercayaan terhadap intensi menggunakan kembali jasa biro psikologi}

Hasil penelitian menunjukkan kepercayaan merupakan faktor penting untuk konsumen dalam memilih dan menggunakan suatu biro psikologi dalam pelaksanaan tes psikologi di sekolah mereka. Berdasarkan indikator yang linear dari kepercayaan yaitu kejujuran, pelanggan lebih menyukai biro psikologi yang selama melakukan proses tes psikologi lebih terbuka kepada pelanggan tersebut, pelanggan lebih tertarik apabila biro jasa menjelaskan mengenai apa saja yang akan dilakukan selama proses tes berlangsung. Hasil penelitian menunjukkan kesesuaian dengan hipotesis penelitian yang menyatakan kepercayaan berpengaruh positif terhadap intensi menggunakan kembali jasa biro psikologi pada konsumen. Setiap peningkatan dari kepercayaan akan meningkatkan intensi menggunakan kembali jasa biro psikologi pada konsumen adalah sebesar 31.5 persen.

Costabile (1998) dalam Ferrinadewi (2008) tentang kepercayaan atau trust didefinisikan sebagai persepsi akan kehandalan dari sudut pandang konsumen didasarkan pada pengalaman. Kepercayaan merupakan perasaan aman konsumen dalam interaksinya dengan merek berdasarkan harapan pasti dari kehandalan (reliability) dan tujuan (intentions) merek. 
Hasil penelitian ini senada dengan penelitian yang dilakukan oleh Lodan \& Anshori (2013) dikatakan hasil penelitian menunjukkan bahwa information quality dan trust berpengaruh terhadap intensi pembelian konsumen secara online pada Lady Reptile, baik secara simultan maupun parsial. Hasil senada juga ditunjukkan oleh penelitian yang dilakukan oleh Han (2014) menyatakan bahwa faktor kepercayaan memiliki pengaruh yang positif terhadap minat membeli yang dilakukan pada situs Weibo. Akan tetapi hasil berbeda ditunjukkan oleh penelitian yang dilakukan Archa (2016) mengatakan bahwa tidak ada pengaruh dari variabel kepercayaan terhadap intensi.

\section{KESIMPULAN}

Berdasarkan hasil penelitian yang dilakukan maka dapat disimpulkan bahwa: pertama, variabel kualitas layanan dan potongan harga memiliki pengaruh positif terhadap kepercayaan. Kedua, variabel kualitas layanan, potongan harga, dan kepercayaan memiliki pengaruh positif terhadap intensi menggunakan kembali jasa biro psikologi. Ketiga, variabel kepercayaan mampu memediasi pengaruh antara kualitas layanan terhadap intensi menggunakan kembali jasa biro psikologi. Keempat, variabel kepercayaan mampu memediasi pengaruh antara potongan harga terhadap intensi menggunakan kembali jasa biro psikologi.

\section{IMPLIKASI MANAJERIAL}

Berdasarkan hasil analisis dan kesimpulan dari penelitian ini diharapkan dapat memberikan manfaat bagi para penggiat bisnis biro psikologi dalam hal penerapan kualitas layanan, potongan harga dan kepercayaan. Implikasi atau manfaat dari penelitian ini adalah sebagai panduan para penggiat bisnis biro psikologi dapat lebih memperhatikan dan meningkatkan mutu pelayanan dan memperbaiki kinerja pelayanan agar citra biro psikologi yang dijalankan dapat melekat dihati konsumen dan akan selalu memanfaatkan biro psikologi yang dimiliki dalam pelayanan tes psikologi. Para penggiat bisnis biro psikologi dapat lebih mengembangkan strategi pemasaran seperti pemberian potongan harga dalam upaya menarik para konsumen untuk kembali menggunakan jasa biro psikologi yang dimiliki. Para penggiat bisnis biro psikologi dapat lebih memperhatikan faktor kepercayaan yang harus dibangun antar Biro dengan konsumennya, hal ini dapat membangun komitmen yang lebih baik sehingga para konsumen tidak memakai biro psikologi lain.

\section{SARAN BAGI PENELITIAN SELANJUTNYA}

Peneliti selanjutnya dapat melakukan penelitian lebih lanjut dengan memilih menggunakan responden yang lebih luas lagi seperti dari tingkatan TK hingga SMA agar jumlah responden yang didapat lebih banyak dan beragam. Peneliti selanjutnya juga dapat menggunakan variabel lainnya sebagai independen variabel seperti bauran pemasaran dan faktor psikologis agar independen vaiabel yang menyebabkan konsumen memiliki keinginan untuk menggunakan kembali jasa biro psikologi menjadi lebih beragam. Menggunakan variabel mediasi lain seperti faktor kepuasan 
konsumen terhadap intensi menggunakan kembali jasa biro psikologi juga dapat dilakukan oleh para peneliti selanjutnya.

\section{DAFTAR PUSTAKA}

Adiatma, O.R., Sudrajat, Drajat. (2013). Analisis Pengaruh Service Quality Terhadap Trust Serta Dampaknya Terhadap Loyalitas. Universitas Bina Nusantara. Jakarta. pp. 1-13.

Ajzen, I. (1991). The theory of planned behavior. organizational behavior and human decision process, Journal of Consumer Behavior, University of Massachusetts at Amherst, Vol. 50. pp. 179-211.

Ajzen, I. (2005). Attitude, personality, and behavior. Open University Press.

Akbar, Muhammad Muzahiddan Parvez, Noorjahan. (2009). Impact of sevice quality, trust and customer satisfaction on customer loyalty. Journal of ABAC. Vol. 29, No. 1. pp.24-38.

Anderson W Eugene, Fornel Cleas \& Lehman R Donald. (1994). Customer Satisfaction, Markel Share, and Profitability: Findings from Sweden. Journal of Marketing, Vol. 58. pp. 53-66

Andilala,Edo., Bachtiar, Fitra., Saputra, Chandra (2005) "Analisis Pengaruh Harga, Persepsi Ukuran, Persepsi Reputasi, dan Kualitas Layanan Terhadap Kepercayaan Konsumen Menggunakan Transportasi Online", Journal Pengembangan Teknologi Informasi dan Ilmu Komputer, Vol. 2 No. 4, pp. 1638-1647

Amstrong, Gary \& Philip, Kotler. (2002). Dasar-dasar Pemasaran. Jilid 1, Alih Bahasa Alexander Sindoro dan Benyamin Molan. Jakarta: Penerbit Prenhalindo

Ariyatiningsih, Febri \& Ediyanto (2016). “Peran Kepuasan dan Kepercayaan Dalam Memediasi Pengaruh Bauran Pemasaran Terhadap Loyalitas Konsumen Pada PT. Bintang Mas Indonesia", Jurnal Ekonomi dan Bisnis GROWTH, Vol. 14, No. 1, pp. 41-58

Arnould, E., Price, L., \& Zinkhan, G. (2004). Consumer 2nd ed. Boston, Massachusetts: The McGrawHill Companies.

Assauri, Sofjan. (2008). Manajemen Produksi dan Operasi. Lembaga Penerbit Fakultas Ekonomi Universitas Indonesia. Jakarta.

Assael, H. (1998). Consumer behavior and marketing action. Ohio: Cincinnati/South-Western.

Basu, Swastha. 1999. Azas-Azas Marketing. Edisi III. Yogyakarta: Liberty

Benhardo, Chandra. (2015). Pengaruh Service Quality Terhadap Customer Behavioral Intention Dengan Mediasi Customer Satisfaction (Studi Kasus Pada Jasa Reflexology di Jakarta. Journal of Marketing. Universitas Bina Nusantara. Jakarta. pp. 49-67.

Barnes, J. G. (2003). Secrets of Customer Relationship Management. Yogyakarta

Boyd, Harper W., Orville C. Walker dan Jean-Claude Larrenche. 2000, Manajemen Pemasaran: Suatu Pendekatan Strategis dengan Orientasi Global. Jilid 2. Edisi Kedua. Alih Bahasa: Imam Nurmawan. Jakarta: Penerbit Erlangga. 
Chaplin, J.P. (2008). Kamus lengkap psikologi. PT. Raja Grafindo Persada

Delgado-Ballester, Elena, Munuera-Aleman, Jose Louis \& Yague-Guillen, Maria Jesus. (2003). Development and Validation of a Brand Trust Scale, International Journal of Market Research, vol. 45/1, pp. 35-53.

Denniswara, Edo Praditya. (2016). Pengaruh Kualitas Produk, Harga dan Promosi terhadap Intensi Membeli Ulang Produk My Ideas. Journal of Business Management. Vol. 1. Universitas Ciputra. pp. 480-488.

Dutka (1994). Atribut - Atribut Dari Konsumen Secara Universal. Erlangga, Glora Aksara Pertama. Jakarta.

Engel, F.J., Blackwell, D. R. and Miniard, P.w. (1990). Consumer behavior. International Edition. The Dryden Press.

Engel, F.J., Blackwell, D. R. and Miniard, P.w. (1995). Consumer behavior. Ohio: Thomson/SouthWestern.

Etemadifard, M., Kafashpoor, A., \& Zendehdel, A. (2013). The Effect of Brand Communication and Service Quality in the Creation of Brand Loyalty through Brand Trust (Case Study: Samsung's Representatives Company in Mashhad City. International Journal of Advanced Studies in Humanities and Social Science, vol. 1, pp. 1067-1077.

Faryabi, Mohammad., Kousar Sadeghzadeh., dan Mortaza Saed., "The Effect of Price Discounts and Store Image on Consumer's Purchase Intention in Online Shopping Context Case Study: Nokia and HTC". Journal of Business Studies Quarterly. pp. 197-205.

Ferrinadewi, E. 2008. Merek dan Psikologi Konsumen. Cetakan pertama. Yogyakarata: Graha Ilmu.

Fishbein, M and Ajzen, I. (1975). Beliefs, attitude, intention and behavior: An Introduction to theory and research. United States: Addison Wesley Pub.co.

Fitzsimmons, J. A., Fitzsimmons, M. J. (1994). Service Management, New York: Mc Graw Hill, Inc.

F. Tjiptono \& G. Chandra. Service, (2011). Quality \& Satisfaction. ANDI. Yogyakarta.

Fornell, C. (1992), A national customer satisfaction barometer: the Swedish experience. Journal of Marketing. Vol. 56, January, pp. 6-21.

Gunarsa, Singgih D. dan Ny. Singgih D. Gunarsa, (2000) Psikologi Perkembangan Anak dan Remaja, Jakarta: PT Gunung Mulia.

Gaspersz, Vincent. (1997). Manajemen Kualitas. Jakarta: PT. Gramedia Pustaka Utama.

Gasperz, V. (1997), Manajemen Kualitas: Penerapan Konsep-Konsep Kualitas dalam Manajemen Bisnis Total, Penerbit PT Gramedia Pustaka Utama, Jakarta.

Gitosudarmo, Indriyo. (2000). Manajemen Pemasaran. Edisi Pertama. Yogyakarta: BPFE.

Ghozali, Imam., 2005, Structural Equation Modelling, Badan Penerbit Universitas Diponegoro, Semarang. 
Hassan, P. (2011). Perceived risk, perceived technology, online trust for the online purchase intention in Malaysia. International journal of Business and Management, vol 6 no. 6. pp. 167182.

Huang, Yu-Kai. (2009) The Effect of Airline Service Quality on Passengers Behavioural Intentions Using Servqual Scores: a Taiwan Case Study. Journal of the Eastern Asia Society for Transportation Studies, Vol.8. pp. 1-14.

Komaling, S. dan Suryani, Alit (2017) Peran Kepercayaan Memediasi Kualitas Layanan dengan niat menggunakan kembali (Studi Pada Konsumen Taxi Blue Bird). Journal Manajemen Unud, Vol. 6, No. 12. Pp 6793 - 6817.

Kotler, P. (2000). Marketing Management, The Milennium ed. Upper Saddle River, Nj, Prentice-Hall, Inc.

Kotler dan Keller. (2009). Manajemen Pemasaran. Jilid I. Edisi ke 13 Jakarta: Erlangga.

Kotler, P. \& K.L. Keller. (2012). Marketing management. 14th ed. New Jersey: Upper Saddle River.

Kotler, Philip, dan Amstrong, Gery. (2012). Prinsip-Prinsip Pemasaran. Edisi Tiga Belas. Jilid 1. Erlangga. Jakarta.

Kotler dan Kevin Lane keller. (2012). Principles of Marketing Management. United States: Person Education.

Krajewski, Lee J. dan Ritzman, Larry P. (1990). Operations Management: Strategy and Analysis, 2nd Edition. Massachusetts: Addison-Wesley Publishing Company.

Lovelock, Cristopher H. 1991. Service Marketing. Second Edition, USA: Prentice Hall International.Inc.

McCarthy, E Jerome. (2002). Dasar-dasar Pemasaran. Edisi lima, Jakarta: Erlangga.

Morgan, Robert M and Shelby Hunt. 1994. The Commitment-Trust Theory of Relationship Marketing. Journal of Marketing, pp. 20-38.

Mowen, J.C., dan Minor, M., 2001, Perilaku Konsumen, Edisi 5, Jakarta: PT. Penerbit Erlangga.

Mowen. J. C., dan Minor, M., 2002, Perilaku Konsumen, Jilid 1, Jakarta: PT. Penerbit Erlangga.

Oliver L Ricahrd, (1993). Cognitif Affetive and Attribute Bases of The Satisfaction Respons", Journal of Customer Research, Vol 20. pp. 418-430

Oliver L Ricahrd. (1997). Satisfaction A Behavioral Prespective On the Cunsumer, New York: Mc Graw - Hill. Companies Inc.

Parasuraman, A., Zeithaml, V.A. dan Berry, L.L. 2008. Delivering Quality Service: Balancing Customer Perceptions and Exxpections, The free Press, New York: NY.

A Parasuraman, Valarie A. Zeithaml, and Leonard L. Berry. 1988. Servqual: A Multiple-Item Scale for Measuring Consumer Perceptions of Service Quality. Journal of Retailling, Volume 64, pp. 12-40. 
Raharso, S. (2004). Respon Organisasi Terhadap Keluhan Pelanggan Untuk Evaluasi Pascakonsumen.Usahawan, No.08, Thn. XXXIII, Agustus, pp. 19-26.

Sahin, A., Cemal, Z., and Kitapci, H. (2012). Does Brand Communication Increase Trust? The Empirical Research on Global Mobile Phone Brands. Procedia-Social and Behavioral Sciences, 58, pp. 1361-1369.

Sahin, A., Zehir, C., and Kitapci, H. (2011). The Effect of Brand Experiences, Trust and Satisfaction on Buliding Brand Loyalty; An empirical Research on Global Brands. Procedia- Social and Behavioral Sciences, 24, pp. 1288-1301.

Sahin, A., Kitapci, H., and Zehir, C. (2013). Creating Commitment, Trust and Satisfaction for a Brand: What is the Role of Switching Cost in Mobile Phone Market. Procedia-Social and Behavioral Sciences, 99, p. 496-502.

Schiffman, Leon G., Kanuk, Leslie Lazar. (2007). Perilaku Konsumen. Alih Bahasa: Zoelkifli Kasip. Jakarta: Indeks.

Schiffman, Leon G., Kanuk, Leslie Lazar. (2008). Perilaku Konsumen. Edisi Ketujuh. Alih Bahasa: Zoelkifli Kasip. Jakarta: Indeks.

Sundalangi, Marchelyno, Silvya, L., Mandey, \& Rotinsulu, J. J. (2014). Kualitas Produk, Daya Tarik Iklan, dan Potongan Harga Terhadap Minat Beli Konsumen Pada Pizza Hut Manado. Jurnal Riset Ekonomi, Manajemen, Bisnis, dan Akuntansi, 2(1). pp. 313-324

Sutisna, (2001). Perilaku Konsumen dan Komunikasi Pemasaran, Remaja Rosdakarya. Bandung.

Sutisna, (2002). Perilaku Konsumen dan Komunikasi Pemasaran, Remaja Rosdakarya. Bandung.

Sutisna, (2003). Perilaku Konsumen dan Komunikasi Pemasaran, cetakan Ketiga, Remaja Rosdakarya. Bandung.

Seigyoung Auh, (2005) "The effects of soft and hard service attributes on loyalty: the mediating role of trust", Journal of Services Marketing, Vol. 19 Issue: 2, pp.80-92.

Tjiptono, Fandy. 1997, Strategi Pemasaran. Edisi 2. Yogyakarta: Penerbit Andi.

Tjiptono, Fandy. 2006. Pemasaran Jasa. Malang: Bayumedia Publising.

Tjiptono, Fandy. 2008. Strategi Pemasaran. Edisi 2. Yogyakarta: Penerbit Andi.

Usmara, Usi. (2008). Pemikiran Kreatif Pemasaran. Amara Books, Yogyakarta. 